\title{
アルミニウム/窒化アルミニウム界面の 冷熱サイクル試験による破壊機構
}

\author{
長友義幸 ${ }^{1}$ \\ 北原丈嗣 1 長瀬敏 之 ${ }^{1}$ \\ 黒光祥郎1 Harini Sosiati ${ }^{2}$ 桑野範 $之^{3}$
}

\author{
1三菱マテリアル株式会社中央研究所 \\ 2九州大学超高圧電子顕微鏡室 \\ 3九州大学産学連携センター
}

J. Japan Inst. Metals, Vol. 72 , No. 6 (2008), pp. 433-439

(C) 2008 The Japan Institute of Metals

\section{Fracture Mechanism of Interface between Aluminum and Aluminum Nitride during Thermal Cycling}

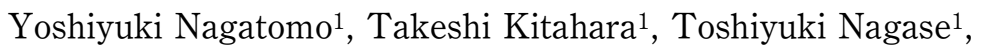
Yoshirou Kuromitsu ${ }^{1}$, Harini Sosiati ${ }^{2}$ and Noriyuki Kuwano ${ }^{3}$

${ }^{1}$ Central Research Institute, Mitsubishi Materials Corporation, Naka, 311-0102

${ }^{2}$ High Voltage Electron Microscopy Laboratory, Kyushu University, Fukuoka 812-8580

${ }^{3}$ Art, Science and Technology Center for Cooperative Research, Kyushu University, Kasuga 816-8580

Fracture mechanism of the interface between an aluminum layer and an aluminum nitride plate during thermal cycling was studied. Observation of the interface with an ultrasonic flaw detector indicated that a crack was generated at an edge of the aluminum layer after approximately 2000 thermal cycles. Cross-section observation using SEM-ASB (Angle Selective Backscattered electron detector) revealed that the crack propagated into the aluminum layer and ran along the interface. The size of aluminum grains around the tip of the crack is $0.2-1.0 \mu \mathrm{m}$. This size is much smaller than that in the initial aluminum layer, which was approximately $500 \mu \mathrm{m}$. It is considered that the reduction in the size of aluminum grains was due to the accumulation of strains in the aluminum layer during the thermal cycling. Observations using SEM-ASB of higher magnification and TEM revealed that the crack was formed in the aluminum layer during thermal cycling, and propagated along the aluminum grain boundaries.

(Receives December 4, 2007; Accepted February 27, 2008)

Keywords: aluminum, aluminum nitride, interface, scanning electron microscope-electron backscatter diffraction, scanning electron microscope-angle selective backscattered electron detector, transmission electron microscopy, fatigue fracture

\section{1. 緒言}

$\mathrm{Y}_{2} \mathrm{O}_{3}$ などの助剤を添加して作製された $\mathrm{AlN}$ 焼結体は高い 電気絶縁性と熱伝導率を有することから, 高出力スイッチン グ素子実装用の絶縁回路基板に広く用いられている.これら 絶縁回路基板には, $\mathrm{AlN}$ 板の両面に $\mathrm{Cu}$ を接合した $\mathrm{Cu}$ 回路 基板と, $\mathrm{Al}$ を接合した $\mathrm{Al}$ 回路基板がある. 従来は電気伝導 性, 熱伝導性に優れた $\mathrm{Cu}$ 回路基板が多く用いられてきた が，冷熱サイクル試験において AlN 内にクラックが発生す るなど, 耐久性に問題があり, 高信頼性を要求される用途に ついては $\mathrm{Al}$ 回路基板が積極的に用いられるようになってき ている11. 冷熱サイクル試験における $\mathrm{Cu}$ 回路基板と $\mathrm{Al}$ 回路 基板の差異は, 塑性変形領域での $\mathrm{Cu}$ と $\mathrm{Al}$ の変形応力挙動 の差で説明できることが弾塑性熱応力解析により明らかとな っている.すなわち, 冷熱サイクル試験において, $\mathrm{Cu}$ と $\mathrm{Al}$ は AlN との熱膨張係数差から繰返し塑性歪みを受けてお り, 加工硬化がより顕著な $\mathrm{Cu}$ においては, 塑性歪みの蓄積 により变形応力が上昇し, それに伴って AlN などへの負荷
も大きくなっていく。一方， $\mathrm{Al}$ では塑性歪みを蓄積して も, 加工硬化は顕著には見られないため, AlNへの負荷に 経時変化はほとんど見られないという結果が得られてい $ろ^{2,3)}$.

$\mathrm{Al}$ 回路基板の製造方法には, $\mathrm{Al}-\mathrm{Si}$ 系や $\mathrm{Al}-\mathrm{Cu}$ 系などの ロウ材を用いて接合するロウ付け法と, AlN がセットされ た鋳型に溶融 $\mathrm{Al}$ を流し込み, 溶融 $\mathrm{Al}$ を凝固させることで 製造する鋳造法の 2 種類がある。いずれの方法も溶融 $\mathrm{Al}$ を $\mathrm{AlN}$ に接触させることで $\mathrm{Al} / \mathrm{AlN}$ 間の接合を確保する製法で ある．溶融 $\mathrm{Al}$ と AlN は濡れ性が悪く, 界面反応が起こりに くい系であるとされているが4)，第一原理計算によれば $\mathrm{Al} /$ $\mathrm{AlN}$ 界面結合力は, 界面反応が起こらなくても, Al 母材の 結合力とほぼ同じであると見積もられている5. 実際, Al/ $\mathrm{AlN}$ ナノ複合材を破壞した際に界面破壊モードが見られな いという実験結果 ${ }^{6)}$ は, 界面反応がなくても十分な界面結合 力を確保できることを示すものである.

冷熱サイクル試験における $\mathrm{Al}$ 回路基板の有効性は, パ ワーモジュールなどのシステム評価や熱応力解析においては 実証されている.しかしながら, 更なる高信頼性化へ向けて 
の材料学的な検討はほとんどなされていない．特に $\mathrm{Al} / \mathrm{AlN}$ 界面近傍には冷熱サイクル試験によって大きなせん断歪みが 発生するので, $\mathrm{Al} / \mathrm{AlN}$ 界面近傍の微構造は信頼性を決定す る重要な因子であると推測される。そこで本研究では， $\mathrm{Al} /$ $\mathrm{AlN}$ 界面の冷熱サイクル試験における微構造の変化を明ら かにし，冷熱サイクル試験における $\mathrm{Al} / \mathrm{AlN}$ 界面の破壊機構 を明らかにすることを目的とする。

\section{2. 実 験方法}

\section{1 試料作製条件}

Fig. 1 に冷熱サイクル試験に供した試料の断面図を示す. $\mathrm{Al} / \mathrm{AlN}$ 接合体は純度 $99.99 \%$ の $\mathrm{Al}$ 板 $(17 \mathrm{~mm} \times 29 \mathrm{~mm} \times 0.6$ $\mathrm{mmt})$ に Al-Si 系のロウ材を介して $\mathrm{AlN}$ 板 $(19 \mathrm{~mm} \times 31 \mathrm{~mm}$ $\times 0.635 \mathrm{mmt}$ )の両面に接合して作製した。接合は約 10-3 $\mathrm{Pa}$ の真空中, 約 $922 \mathrm{~K}$ で行った. その後この接合体を厚さ $5 \mathrm{~mm}$ の Al 合金 (A6063) に真空ロウ付けし，これを冷熱サ イクル試験用試料としたＡ A6063の $\mathrm{Al}$ 合金を $\mathrm{Al} / \mathrm{AlN}$ 接合 体に接合することで，冷熱サイクル試験時の裏面 $\mathrm{Al} / \mathrm{AlN}$ 界 面 (Fig. 1 矢印で示した界面)への負荷が大きくなり，試験を 加速させることが可能になる. 試料中の接合界面は冷熱サイ クル試験に投入する前に超音波探傷(Fine SAT 200 ：日立建 機ファインテック製)で裏面 $\mathrm{Al} / \mathrm{AlN}$ 界面の接合面積を測定 した結果, 全面で接合しており, 剥離は認められなかった.

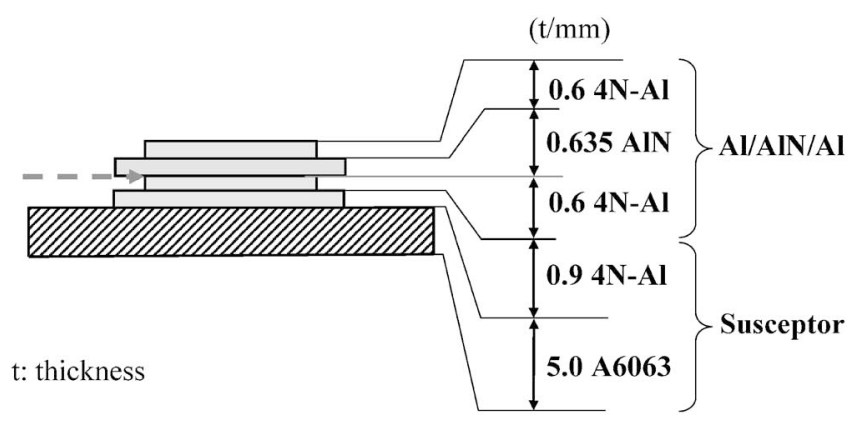

Fig. 1 Schematic image of a specimen-set for thermal cycle test. Cracks are expected near the interface marked with an arrow.

\section{2 冷熱サイクル試験}

冷熱サイクル試験は $233 \mathrm{~K}$ および $378 \mathrm{~K}$ に制御された フロリナートを用意し，それぞれ各 5 分ずつ上記試料を交 互に浸漬することで実施した．試験機はエスペック社製の液 相冷熱試験機 TSB-51 を用いた。界面の破壊進行状況を見 るために 1000 サイクルごとに試料を取り出し, 超音波探傷 で接合面積を測定した。

\section{3 組織観察方法}

冷熱サイクル試験による破壊進行過程を観察するために， 試料の断面組織観察を行った. 組織観察は走査電子顕微鏡 $(\mathrm{SEM})$, 透過電子顕微鏡 $(\mathrm{TEM})$ を用いて行った. SEM 観 察用試料は, ダイヤモンドソーにより断面を切り出しエメ リ一紙による研磨の後, 観察面の平滑化および加工丕除去の ためアルゴンイオンビームによるイオン研磨を行った. SEM 観察では, 電子線後方散乱回折 (Electron Back Scattered Diffracton: EBSD)解析 (S4300 : 日立製作所製)および ASB 検出器 (Angle Selective Backscattered Electron Detector)による反射電子像解析 (Ultra 55: Carl Zeiss 製)を 15〜20 $\mathrm{kV}$ 程度の加速電圧で行った. ASB 検出器は, SEM のポー ルピース先端に設置された環状の検出器で, 試料距離や加速 電圧などの条件を変えることで, 試料表面に対して比較的低 角度に回折した反射電子を選択的に検出することができる. こうして得られた ASB 像では, 通常の反射電子像よりも回 折コントラストが強調されるので, サブグレインや転位など の，TEM 像とほぼ同様の情報を得ることができる7)。TEM 観察用試料は，集束イオンビーム (Focused Ion Beam: FIB) 装置(FB2000K：日立製作所製）を用いて作製した。TEM (JEM-2000EX/T：日本電子製）観察では電子線回折，明視 野像および暗視野像による解析を行った。とくに冷熱サイク ル試験により破壊が発生した箇所に注目して観察を行った.

\section{3. 結果および考察}

\section{1 冷熱サイクル試験前の $\mathrm{Al} / \mathrm{AlN}$ 界面近傍組織}

Fig. 2 は冷熱サイクル試験前の $\mathrm{Al} / \mathrm{AlN}$ 界面近傍について

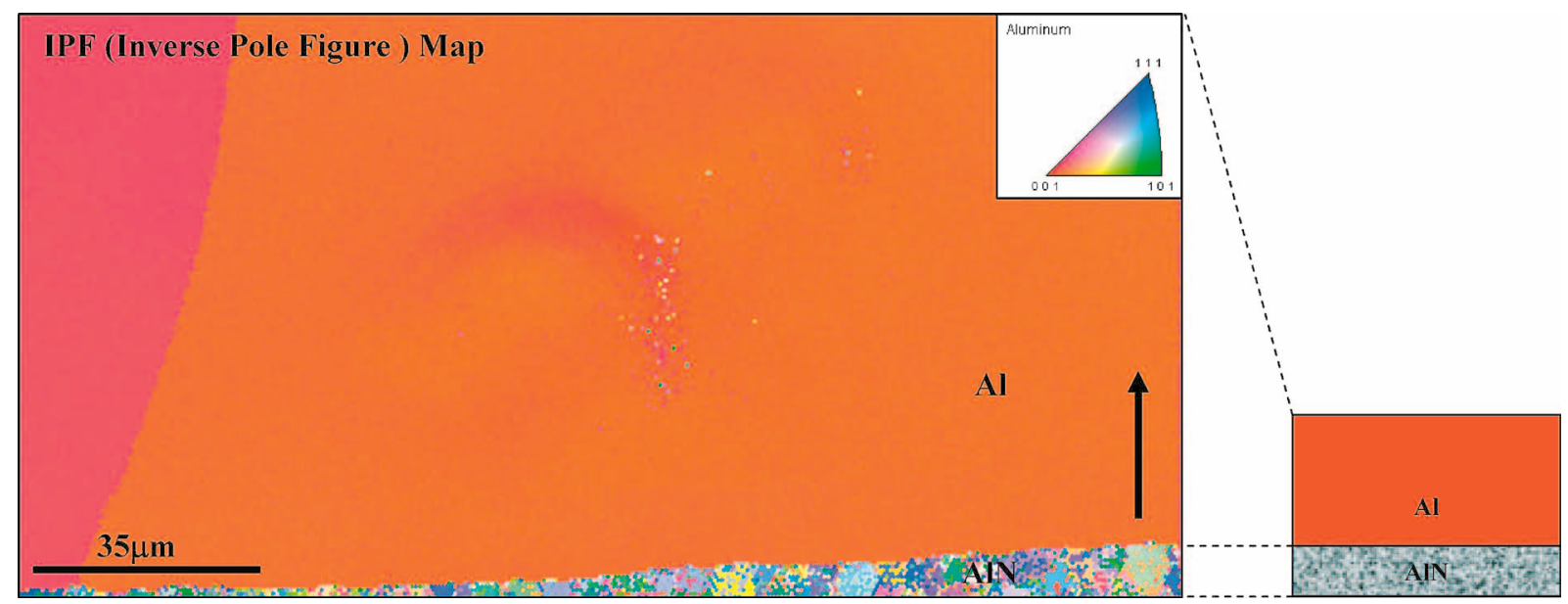

Fig. 2 IPF map of aluminum/aluminum nitride interface before thermal cycle test. 
の $\mathrm{EBSD}$ にる $\mathrm{Al}$ 結晶方位マップである。図中矢印の方 向，すなわち $\mathrm{Al} / \mathrm{AlN}$ 界面に対して法線方向の $\mathrm{Al}$ 結晶方位 を示している。 $\mathrm{Al}$ は，ほぼ全域にわたって $[001] \mathrm{Al}$ 方位が $\mathrm{Al} / \mathrm{AlN}$ 界面に対して垂直になっていることがわかる．純度 99.99\%以上の $\mathrm{Al}$ 板は, 圧延加工後の熱処理により立方体方 位粒が優先的に成長することがよく知られている8 が，本試 料の口ウ付け時の熱処理においても, 立方体方位粒の優先成 長が起きたと推察される.これら $\mathrm{Al}$ 板の立方体方位粒の粒 径は, 接合面方向で $0.5 \sim 1 \mathrm{~mm}$, 垂直方向で $0.6 \mathrm{~mm}$ であっ た。 また， $\mathrm{A} 1$ ロウと $\mathrm{A} 1$ 板との結晶方位による区別は明確に はできない。このことから，溶融した Alロウは，ロウ付け 中に成長した $\mathrm{A} 1$ 板の立方体方位を引き継ぎながら凝固した と考えられる。

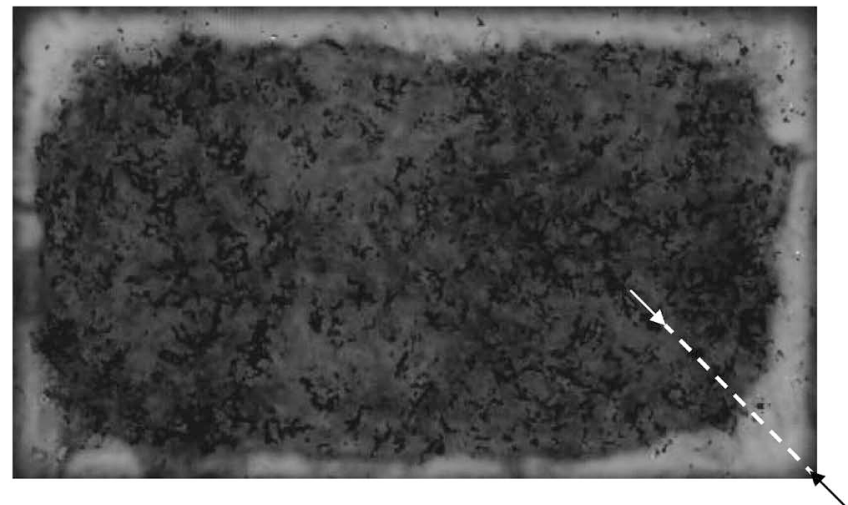

Fig. 3 Observation of aluminum/aluminum nitride interface with ultrasonic flaw detector. Specimen for cross-section observation was prepared with cutting along the brake line.

\section{2 冷熱サイクル試験による $\mathrm{Al} / \mathrm{AlN}$ 界面剥離の進展}

Fig. 3 は前述試料に冷熱サイクル試験(4000 サイクル)を 施した後, $\mathrm{Al} / \mathrm{AlN}$ 界面の接合状態を接合面に垂直方向から 超音波探傷で観察した結果を示す。探傷画像中の白い場所が $\mathrm{Al} / \mathrm{AlN}$ 界面で剥離が進行している部分である。剥離は 2000 サイクル程度から $\mathrm{Al}$ の端部より発生し始め, 徐々に中 央に向かって進展していく，特に $\mathrm{Al}$ コーナー部は剥離の進

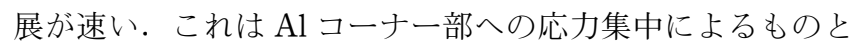
考えられる.

\section{$3.3 \mathrm{Al} / \mathrm{AlN}$ 界面剥離部の断面組織観察}

剥離部の微構造解析をするために, 剥離の進展の速い $\mathrm{Al}$ コーナ一部 (Fig. 3 中の破線部) を切断し, 断面観察試料を作 製し，SEM 観察に供した。 Fig. 4 は冷熱サイクル試験 4000 サイクル後の剥離発生・進展が顕著に見られた部位の SEM によるASB 像で，Fig. 5 はその一部を拡大したものである.

Fig. 4, Fig. 5 中，上側の明るいコントラストを呈している 領域が $\mathrm{Al}$ である. Fig. 4 の矢印は超音波探傷で観察された 剥離である. 剥離は $\mathrm{Al} / \mathrm{AlN}$ 界面近傍で, $\mathrm{AlN}$ 側に $\mathrm{Al}$ を数 $\mu \mathrm{m}$ 程度残しながら $\mathrm{Al}$ 内部を進展しているクラックによる ものであることがわかる。これは，今回確認された剥離は $\mathrm{Al}$ の繰返し歪みによる疲労破壊の結果であることを示唆し ている. Fig. 4, Fig. 5 の Al 内には $\mathrm{Al}$ 結晶方位に依存した 回折コントラストが観察される. $\mathrm{Al}$ の結晶粒は冷熱サイク ル前 (Fig. 2) と比べて, 繰返し歪久の影響で約 $3 \mu \mathrm{m}$ 以下に まで細かくなっている．特に $\mathrm{Al} / \mathrm{AlN}$ 界面から約 $100 \mu \mathrm{m}$ 以 内の領域における $\mathrm{Al}$ 結晶粒の微細化は顕著である(Fig. 5).これは, 冷熱サイクル試験による繰返し塑性歪みが $\mathrm{Al} /$

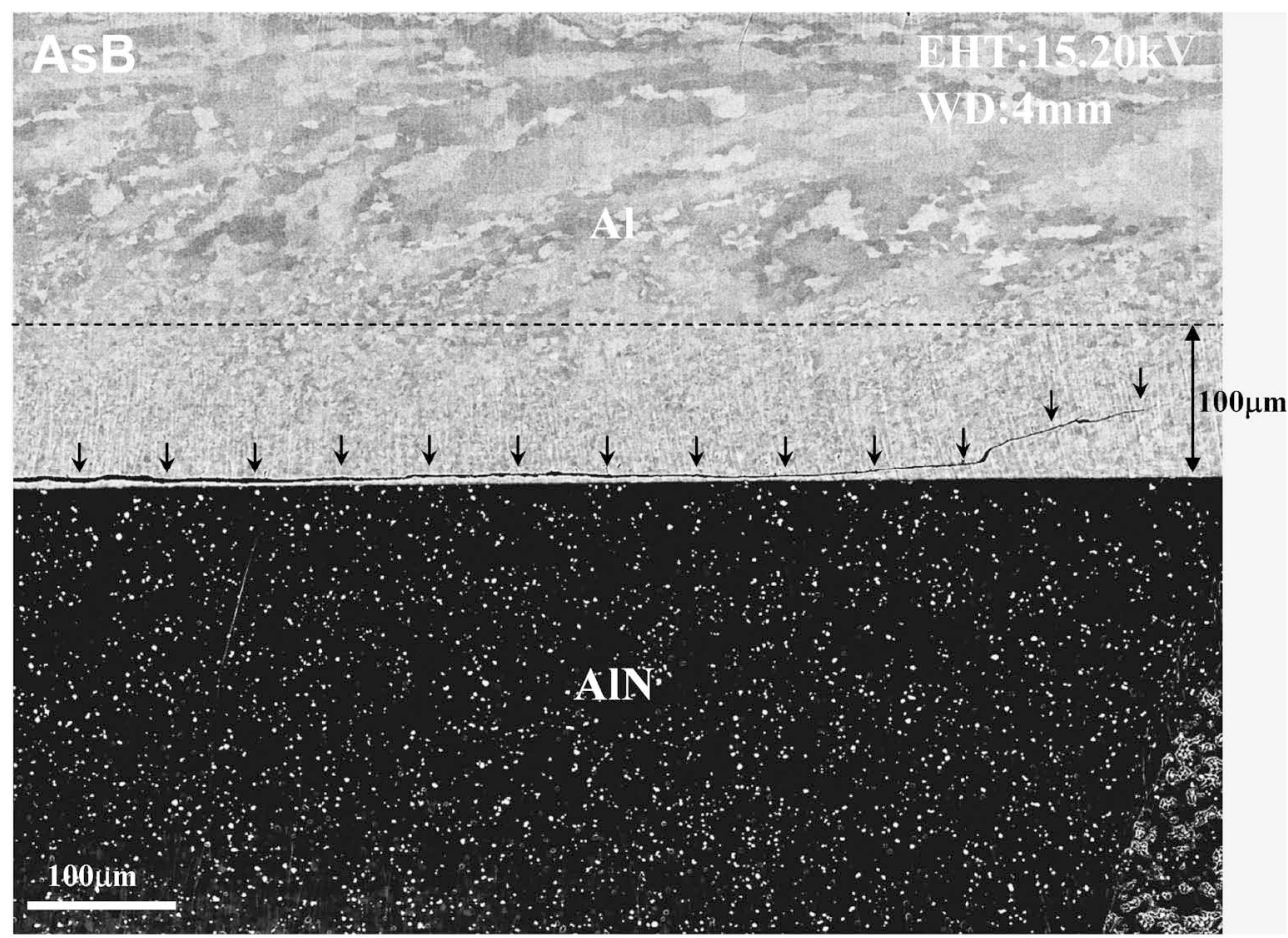

Fig. 4 SEM-ASB image of aluminum/aluminum nitride interface after thermal cycle test. Arrows show the crack in aluminum layer. 


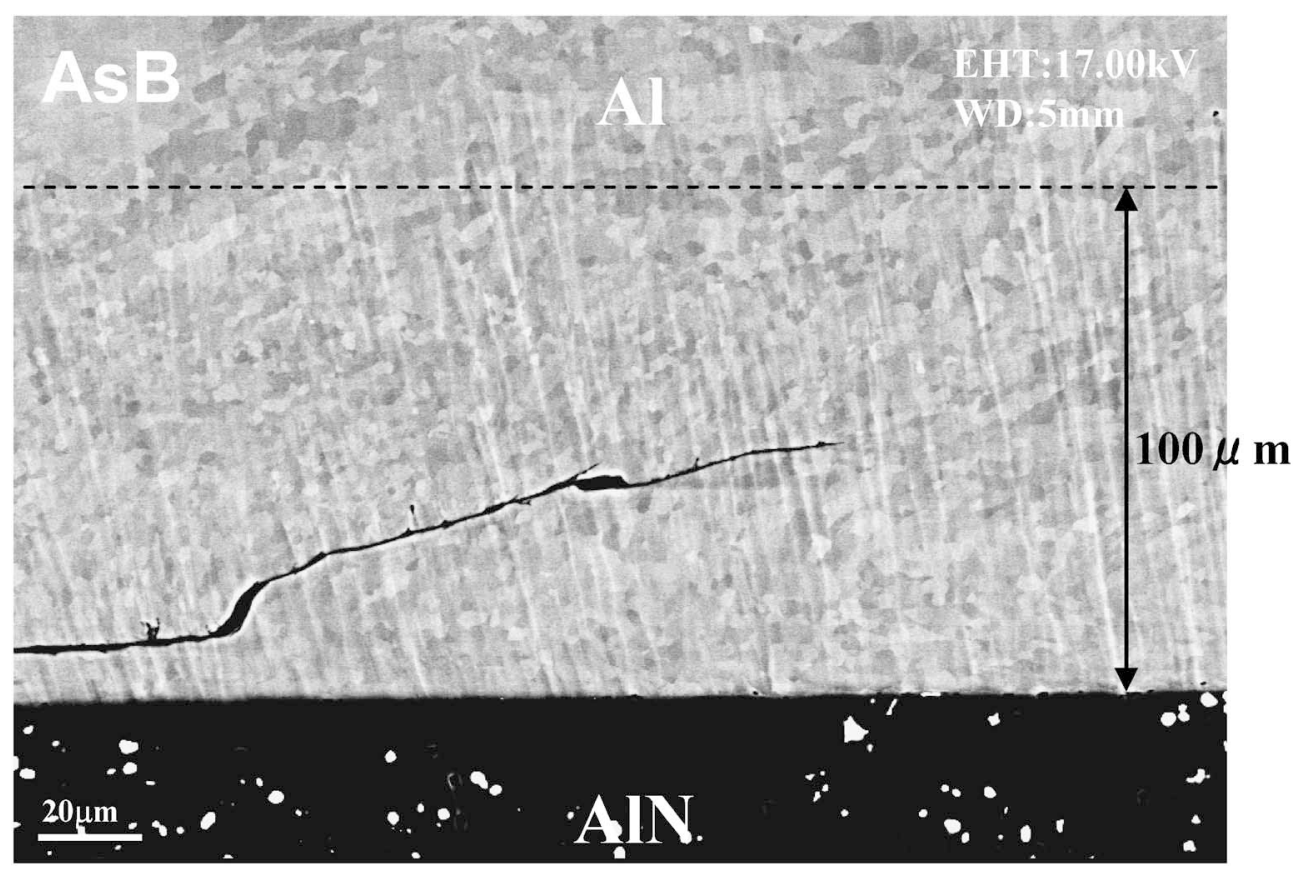

Fig. 5 SEM-ASB image of crack in aluminum layer.

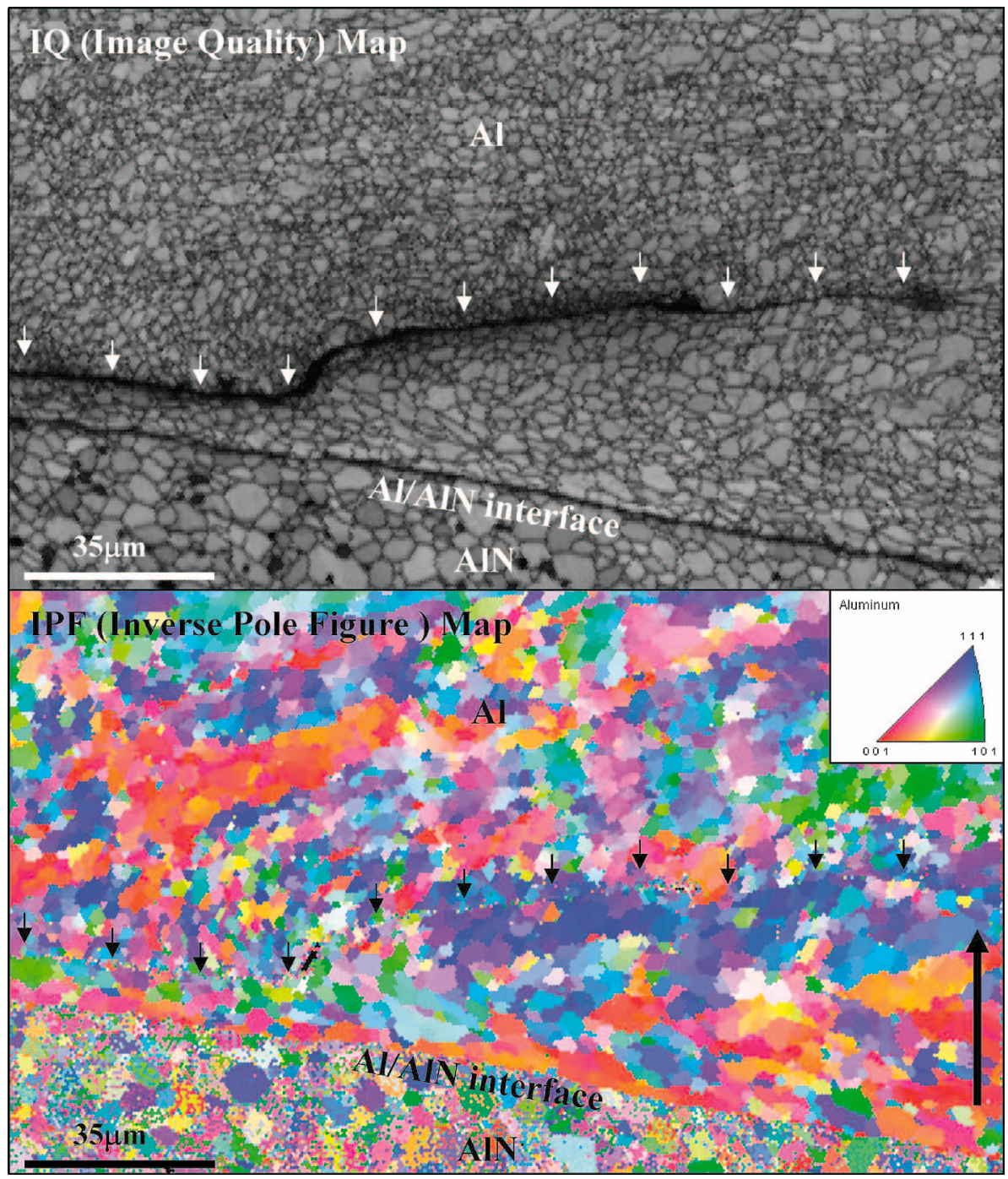

Fig. 6 IQ map and IPF map of aluminum/aluminum nitride interface after thermal cycle test. 


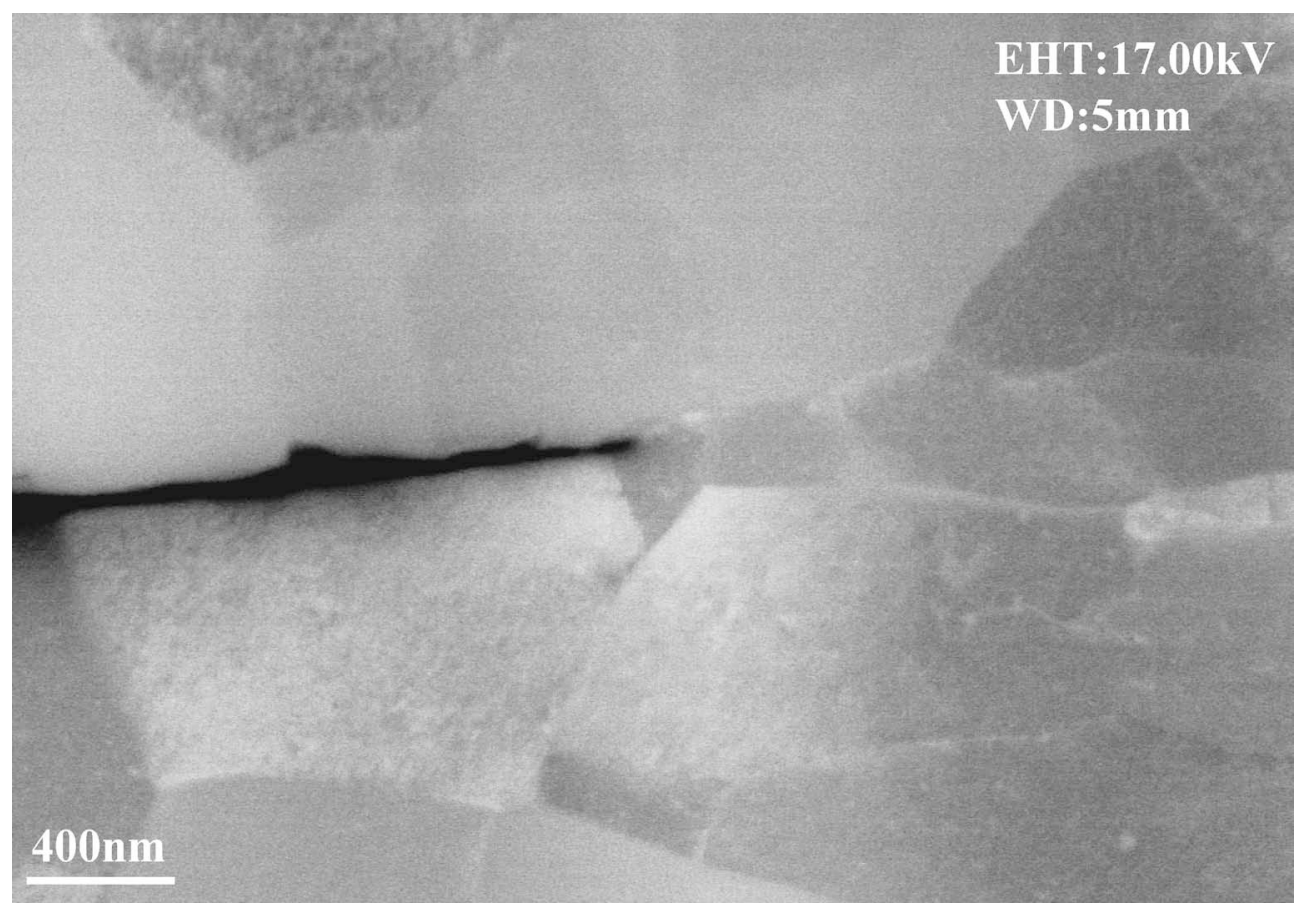

Fig. 7 SEM-ASB image of tip of crack in aluminum layer. Aluminum grains are observed clearly with diffraction contrast.

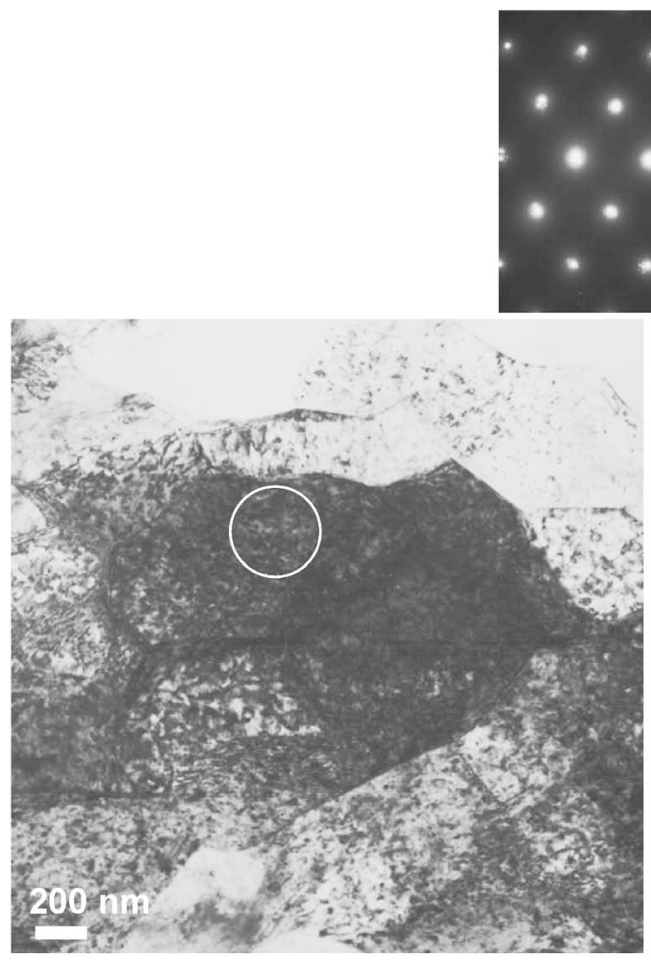

(a)

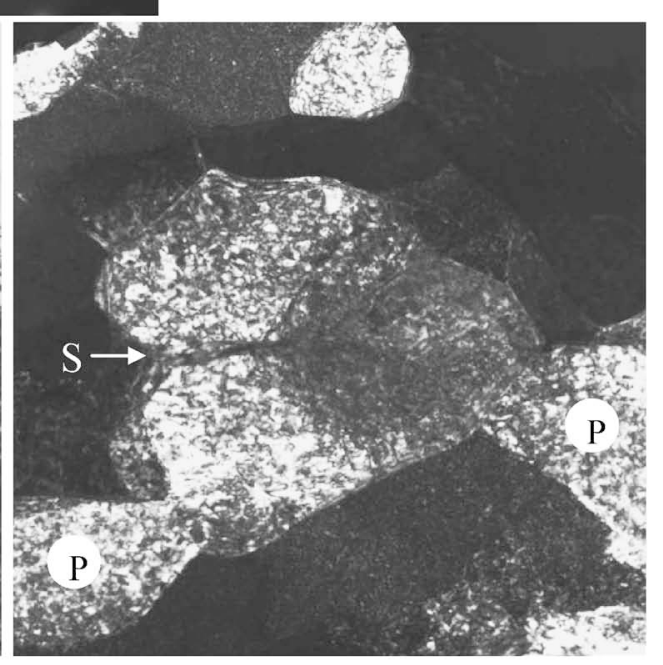

(b)

Fig. 8 Diffraction pattern and TEM images of aluminum nearby tip of crack after thermal cycle test. (a): bright field image and (b): dark field image.

AlN 界面近傍に集中していることを示唆する.

Fig. 6 はクラック先端近傍領域の SEM-EBSD による IQ (Image Quality)マップと Al 結晶方位マップを示したもので ある. 微細化した $\mathrm{Al}$ の結晶方位は, 冷熱サイクル試験前に 見られた立方体方位がほぼ消失した状態になっていることが わかる. またクラック近傍の $\mathrm{Al}$ の結晶方位は $\mathrm{Al} / \mathrm{AlN}$ 界面
に対して垂直な方向に，[111 $]_{\mathrm{Al}}$ 方位がそろっている傾向が 見られる.これは冷熱サイクルによって生じたせん断歪みに よって, Alのすべり面(111) $\mathrm{Al}$ 面が配向しながらクラックが 進展したものと思われる. クラック先端をさらに高倍率で観 察すると，このクラックは微細化した $\mathrm{Al}$ の結晶粒界に沿っ て進展していることがわかる(Fig. 7).クラック先端の $\mathrm{Al}$ 


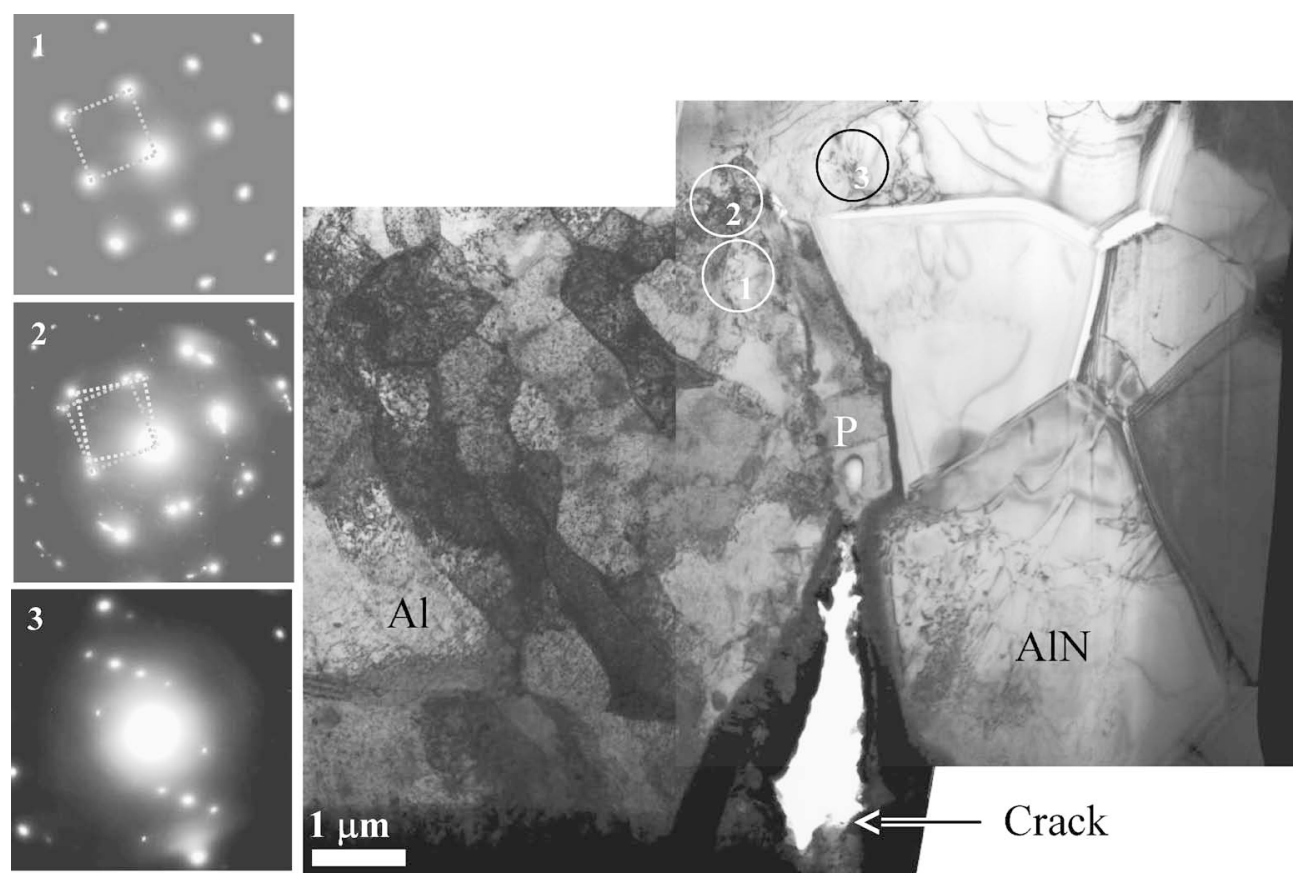

Fig. 9 Diffraction patterns and bright field image around the tip of crack in aluminum layer.

結晶粒径は $0.2 \sim 1.0 \mu \mathrm{m}$ 程度まで微細化されている. ASB 像のコントラストは, 試料表面近傍で回折した反射電子から 得られるので, TEM の回折コントラストと類似した情報が 得られると考えられる. $\mathrm{Al}$ の結晶粒内は転位などによる歪 みが要因と思われるコントラストが散見される.

以上の結果より, $\mathrm{Al}$ は冷熱サイクルにより塑性歪みを蓄 積した結果, 立方体方位を壊しながら $\mathrm{Al}$ 結晶粒微細化が進 行すると考えられる. 結晶粒微細化は抢よそサブミクロンの オーダーまで進行し, 最終的には $\mathrm{Al}$ 結晶粒界での破壊に至 ると考えられる.

\section{$3.4 \mathrm{Al} / \mathrm{AlN}$ 界面のクラック発生・進展機構}

上述の $\mathrm{Al}$ 結晶粒微細化打よびクラックの発生・進展機構 を明らかにするために，別の試料を用いてクラック近傍の組 織をTEM で観察した。

Fig. 8 はクラック近傍から FIB によりマイクロサンプリ ングした Al 結晶粒の TEM 像である。（a）は明視野像，(b) は $h k l=200$ 反射による暗視野像である.画面中央の結晶粒 は, 結晶粒内に発達した横方向(この結晶粒では $[100]$ )の転 位の束が束ねられて粒界が形成されている様子がわかる。こ れに伴い結晶粒の左側から窪んできて抢り(矢印 S), 変形が 進んで結晶粒が上下に分割しつつある。これに対して，左右 にはほとんど同じ方位の結晶粒 $(\mathrm{P})$ はほとんど繋がりを見せ ている.すなわち, 結晶粒の変形により横方向に長い結晶粒 の形成が進行している。このように, 繰返し歪みにより転位 の発生と集合が抢こることで，新しい粒界が形成され， $\mathrm{Al}$ の結晶粒微細化が進行するものと思われる。このような転位 の集合が繰り返され，遂にはクラックへと発展するものと考 えられる.

Fig. 9 は，クラックが発生した $\mathrm{Al} / \mathrm{AlN}$ 界面を含む領域の $\mathrm{TEM}$ 像である.クラック先端部付近の $\mathrm{Al}$ 結晶粒は，上述

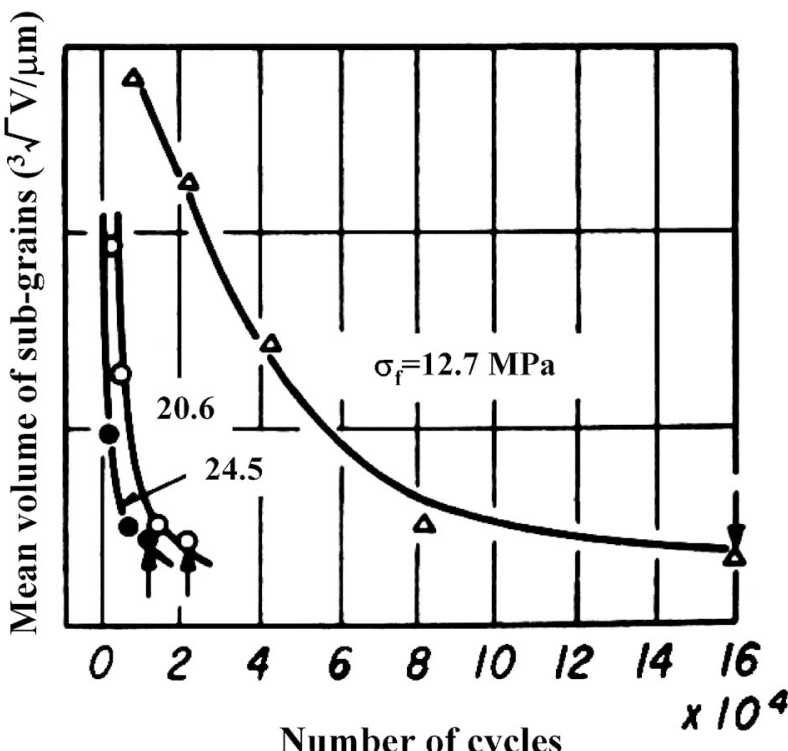

Fig. 10 Variation of sub-grain size of aluminum with alternating stress $\left(\sigma_{f}\right)$ and number of cycles. The arrows show the points of crack generation ${ }^{9}$.

の ASB 像と同様に, $1 \mu \mathrm{m}$ 程度ときわめて小さくなってい る. (1)，(2)の結晶粒はともにほとんど同じ結晶方位をもつが, (2)の粒からの回折パターンからもわかるように結晶粒の回転 が認められる。像コントラストから, 結晶粒(1)の内部はさら に細かい領域に分割している様子が伺われる。これは Fig. 8 で示したように転位の集合により亜粒界が形成されているこ とを示している。

$\mathrm{Al}$ の引張・圧縮繰返し試験により発生した疲労クラック 先端付近の $\mathrm{Al}$ 結晶粒サイズは, 振幅応力值によらず常に一 定になることが知られている(Fig. 10 ${ }^{9)}$ ．今回 $\mathrm{Al} / \mathrm{AlN}$ 界面 
近傍で観察された $\mathrm{Al}$ 内クラック先端近傍部の $\mathrm{Al}$ の結晶粒 サイズが，複数の試料においてサブミクロンから数 $\mu \mathrm{m}$ オー ダーのサイズで一致していたという結果は， $\mathrm{Al} / \mathrm{AlN}$ 界面近 傍のクラックが $\mathrm{Al}$ の疲労破壊で発生・進展したことを支持 するものであると考えられる，また，転位の発生・移動によ り $\mathrm{Al}$ 結晶粒微細化が進行したことを考慮すると, 疲労破壊 抑制には, $\mathrm{Al}$ 結晶粒サイズの疲労破壊臨界值(サブミクロン 〜数 $\mu \mathrm{m})$ に至るまでに, 分散粒子などを析出させるなどし て転位の移動を妨げ, $\mathrm{Al}$ 結晶粒微細化の進行を遅らせるこ とが有効であると予想される.

\section{4. 結言}

(1) $\mathrm{Al} / \mathrm{AlN}$ 接合体に冷熱サイクル試験を実施し，約 2000 回以降の高サイクルで $\mathrm{Al}$ 端部からクラックが生じた.

(2) このクラックは主に $\mathrm{Al} / \mathrm{AlN}$ 界面から $10 \mu \mathrm{m}$ 以内の $\mathrm{Al}$ 内部で進展していた。これより $\mathrm{Al} / \mathrm{AlN}$ 接合体の冷熱サ イクルによる破壊モードは $\mathrm{Al}$ の疲労破壊であると考えられ る.

(3) クラック近傍の $\mathrm{Al}$ 結晶粒サイズは $0.2 \sim 1 \mu \mathrm{m}$ 程度で あった。これは冷熱サイクル前のサイズよりかなり細かく, 冷熱サイクル試験により繰返し歪みを受けることで微細化が
進行した結果であると推察される。

(4) クラックは繰返し歪みにより微細化した $\mathrm{Al}$ 結晶粒界 に沿って進展している.

（5） Al 結晶粒微細化は繰返し歪みによって発生・移動し た転位が収束することで元々の結晶粒を分割するように亜粒 界を形成しながら起こると考えられる.

本研究の SEM 観察にご協力いただいたエスアイアイナノ テクノロジー陎の花田剛氏(現 : 株式会社シーゼットアイ), 立花繁明氏に謝意を表する。

\section{文献}

1) T. Harada and Y. Baba: Proceedings of EVS-15, (1998).

2) Y. Nagatomo, T. Nagase and S. Shimamura: J. Japan Inst. Elecronic Packaging 3(2000) 330.

3) Y. Nagatomo and T. Nagase: Proceedings of EVS-17, (2000).

4) H. Fujii and H. Nakae: Materia Japan 34 (1995) 1269.

5) N. Ogata and H. Kitagawa: J. Japan Inst. Metals, 60 (1996) 1079.

6) S. W. Lai and D. D. L. Chung: Electronic Packaging Materials Science VII Symposium, (Mat. Res. Soc. Symp. Proc. Vol. 323) (1994) 207.

7) K. Shimizu, T. Mitani, S. Tachibana and H. Habazaki: J. Japan Inst. Light Metals 56(2006) 454.

8) F. Seki : J. Japan Inst. Metals 64(2000) 218.

9) S. Karashima: Kinzoku-gokinn no kyoudo (in Japanese), (1972) 173. 